\title{
Penyuluhan dan Inisiasi Komitmen Masyarakat dalam Mewujudkan Kawasan Tanpa Rokok sebagai Upaya Perlindungan pada Perokok Pasif
}

\author{
Rony Darmawansyah Alnur ${ }^{*}$, Meita Veruswati ${ }^{2}$ \\ 1,2Fakultas Ilmu-Imu Kesehatan, Universitas Muhammadiyah Prof. Dr. Hamka \\ Email: ronyalnur@uhamka.ac.id ${ }^{1}$,meitaveruswati@uhamka.ac.id ${ }^{2}$ \\ *Corresponding author: ronyalnur@uhamka.ac.id ${ }^{1}$
}

\begin{abstract}
ABSTRAK
Perilaku merokok tidak hanya berdampak pada orang yang merokok tetapi juga pada orang yang terpapar asap rokok atau yang umumnya dikenal sebagai perokok pasif. Menyikapi masalah tersebut perlu adanya peningkatan pengetahuan kepada masyarakat dan komitmen masyarakat untuk menerapkan kawasan tanpa rokok khususnya di fasilitas pelayanan umum sehingga memberikan perlindungan kepada perokok pasif. Pengabdian kepada masyarakat ini dilakukan pada 1 juni 2018 di Kantor Desa Talagasari dengan tujuan memberikan pengetahuan kepada masyarakat tentang bahaya rokok dan menginisiasi komitmen bersama untuk tidak merokok di kantor desa. Peserta pengabdian masyarakat berjumlah 55 orang yang terdiri atas perangkat desa dan masyarakat. Pendidikan kesehatan dengan pendekatan penyuluhan yang didukung dengan pemanfaatan media KIE (Komunikasi Informasi dan Edukasi) yang menarik dan mudah dipahami oleh masyarakat dilakukan dalam pengabdian kepada masyarakat ini. Hasil dari pengabdian kepada masyarakat ini berhasil meningkatkan pengetahuan masyarakat tentang bahaya rokok dan kawasan tanpa rokok masing - masing sebesar 15,27 poin dan 16.00 poin melalui hasil perhitungan Pre-test dan Post-test. Selain itu, pada pengabdian masyarakat ini juga terwujud komitmen masyarakat untuk tidak merokok di kantor desa. Capaian ini diharapkan dapat memperluas kebijakan komitmen untuk tidak merokok di fasilitas pelayanan umum lainnya di Desa Talagasari.
\end{abstract}

Kata kunci: Pengetahuan, Rokok, Kawasan Tanpa Rokok

\begin{abstract}
The impact of smoking behavior not only affects people who smoke but also passive smokers. Responding it, necessary to increase are community knowledge and commitment to implement Smoke-Free Zone, especially in public service facilities to protect passive smokers. This community service was carried out on 1 June 2018 at the Talagasari Village Administration Office with the aim of providing knowledge to the community about the dangers of smoking and initiating a joint commitment not to smoke at the village administration office. The participants were 55 people consisting of village apparatus and community. Health education carried with a counseling approach that supported of Communication, Information and education media were exciting and easily understood by the public to realize this achievement. The results of community service have succeeded in increasing knowledge about the dangers of cigarettes and Smoke-Free Zone by 15.27 points and 16.00 points respectively, through the results of the Pre-test and Post-test. In addition, in this community service, community commitment is also manifested not to smoke at the Village Administration Office. This achievement was being expected to broaden the policy of commitment to not smoking in other public service facilities in Talagasari Village.
\end{abstract}

Keywords: Knowledge, Cigarettes, Smoke-Free Zone 


\section{PENDAHULUAN}

Kesehatan merupakan aspek yang sangat penting bagi kehidupan manusiauntuk hidup produktif secara social dan ekonomis (UndangUndang RI No. 36, 2009). Henrik L. Blum dalam teori mengemukakan bahwa perilaku merupakan salah satu faktor yang mempengaruhi status kesehatan seseorang. Merokok merupakan perilaku sering kita jumpai dilakukan oleh masyarakat baik pada kelompok dewasa maupun remaja. Perilaku merokok di Indonesia menempati urutan ketiga setelah negara Cina dan India (Suryantisa, 2018).

Hasil Riset Kesehatan Dasar tahun 2018 menunjukkan bahwa perokok laki - laki usia $>15$ pada data Riset Kesehatan Dasar tahun 2018 menunjukkan penurunan jika dibandingkan hasil riset sebelumnya di tahun 2013 yakni 66,0\% menjadi $62,9 \%$ (Balitbang Kemenkes RI, 2018). Namun angka ini masih menempatkan Indonesia sebagai salah satu negara dengan prevalensi perokok tertinggi di dunia (Fauzi et al., 2019).

Sebagaimana diketahui bahwa perilaku merokok tidak hanya berdampak pada orang yang merokok tetapi juga pada orang yang tidak merokok yang berada disekitar atau yang biasa disebut sebagai perokok pasif (Kemenkes RI, 2018). Seorang perokok pasif memperoleh $75 \%$ dari bahaya asap rokok karena terpapar secara langsung (Direktorat P2PTM Kemenkes RI, 2018). Hal ini juga didukung oleh data dari Global Youth Tobacco Survey yang menunjukkan $60.1 \%$ remaja di Indonesia terpapar asap rokok di tempat umum (Astuti et al., 2015).
Regulasi yang terkait pengamanan zat adiktif termasuk rokok diatur dalam undang - undang nomor 36 tahun 2009 tentang Kesehatan (Undang-Undang RI No. 36, 2009). Adanya regulasi ini merupakan upaya dalam mewujudkan masyarakat sehat. Pada regulasi lain yang dikeluarkan oleh pemerintah berupa peraturan bersama menteri kesehatan dan menteri dalam negeri No.188/Menkes/PB/I/2011 No. 7 Tahun 2011 tentang Pedoman Kawasan Tanpa Rokok (Peraturan Bersama Permekes \& Permendagri, 2011). Kawasan Tanpa Rokok (KTR) adalah ruangan atau area yang dinyatakan dilarang untuk kegiatan merokok atau kegiatan memproduksi, menjual, mengiklankan dan atau mempromosikan produk tembakau yang meliputi fasilitas pelayanan kesehatan, tempat proses belajar mengajar, tempat bermain anak, tempat ibadah, angkutan umum, tempat kerja, tempat umum dan tempat lainnya (Kemenkes RI, 2011). Adanya regulasi terkait pentingnya kawasan tanpa rokok merupakan tanggung jawab bagi setiap kabupaten/kota untuk mewujudkan Kawasan tanpa rokok dalam bentuk peraturan daerah sebagai upaya untuk memberikan perlindungan hukum bagi masyarakat terhadap paparan asap rokok dari orang lain (Peraturan Pemerintah Republik Indonesia, 2012). Salah satu kabupaten di Indonesia yang belum memiliki peraturan daerah terkait kawasan tanpa rokok adalah Kabupaten Pandeglang. Jika ditinjau dari data Riskesdas tahun 2018 prevalensi perokok di Kabupaten Pandeglang mencapai $37.93 \%$, lebih tinggi dari rerata prevalensi perokok 
di Provinsi Banten yakni 31,5\% (Balitbang Kemenkes RI, 2018).

Hasil kajian kegiatan PBL (Pengalaman Belajar Lapangan) yang dilakukan oleh mahasiswa Program Studi Kesehatan Masyarakat Universitas Muhammadiyah Prof. Dr. Hamka pada 200 responden di Desa Talagasari menunjukkan bahwa perilaku merokok merupakan salah satu masalah prioritas dari berbagai masalah kesehatan yang perlu diintervensi di Desa Talagasari, Kabupaten Pandeglang. Pada kajian tersebut menunjukkan bahwa $85,5 \%$ responden memiliki anggota keluarga yang merokok (Kesmas Uhamka, 2018).

Menyikapi hal tersebut, perlu solusi untuk mengatasi polemik perilaku merokok masyarakat dengan melibatkan peran pemerintah desa dan masyarakat Desa Talagasari. Adapun Langkah yang dilakukan adalah dengan melakukan pengabdian kepada masyarakat dengan tujuan peningkatan pengetahuan masyarakat tentang bahaya rokok dan peran kawasan tanpa rokok serta inisiasi terbentuknya komitmen bersama untuk tidak merokok di Kantor Desa Talagasari.

\section{METODE PENELITIAN}

Kegiatan pengabdian kepada masyarakat ini dilaksanakan pada 1 juni 2018 di Desa Talagasari, Kabupaten Pandeglang. Sasaran dari kegiatan pengabdian kepada masyarakat ini adalah perangkat desa, tokoh masyarakat, tokoh agama, tokoh pemuda dan masyarakat di Desa Talagasari. Metode yang dikembangkan pada pengabdian kepada masyarakat ini berupa pendidikan kesehatan dengan pendekatan penyuluhan (ceramah) yang didukung dengan pemanfaatan media KIE (Komunikasi Informasi dan Edukasi) yang menarik dan mudah dipahami oleh masyarakat. Alur pelaksanaan kegiatan Pengabdian kepada masyarakat dapat dilihat pada gambar 1 .

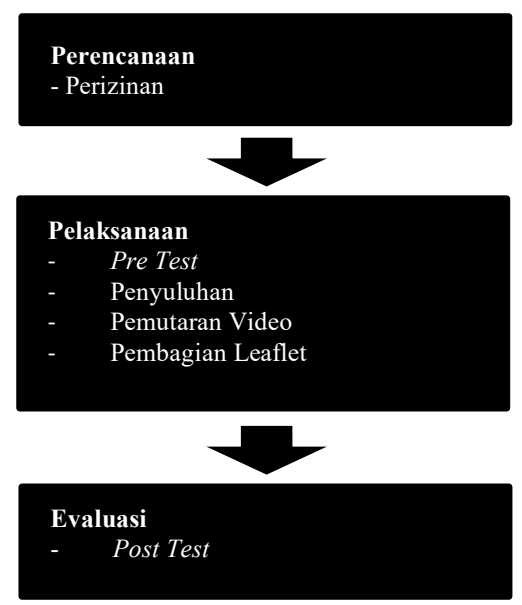

Gambar 1. Alur pelaksanaan kegiatan pengabdian kepada masyarakat

1. Tahap Perencanaan

Tahap perencanaan dimulai dengan pembuatan surat izin kegiatan. Selanjutnya, tim peneliti melakukan sosialisasi awal dengan Kepala Desa Talagasari melalui panggilan handphone terkait rencana kegiatan pengabdian kepada masyarakat.

2. Tahap Pelaksanaan

Untuk mengetahui sejauh mana pengetahuan peserta terkait bahaya rokok dan pentingnya Kawasan Tanpa Rokok, tim pengabdian kepada masyarakat melakukan melakukan registrasi dan pembagian pre-test kepada peserta. Setelah pengisian pre-test selesai dilakukan, kegiatan dilanjutkan dengan memulai penyuluhan yang dilakukan dalam bentuk ceramah dan 
pemutaran video pendek terkait bahaya rokok serta pembagian leaflet tentang bahaya rokok.

Pada kegiatan ini juga terdapat media informasi pendukung yang menarik dan mudah dipahami masyarakat berupa: PIN, poster bahaya rokok, jam dinding, godybag berisi pesan kesehatan, dan spanduk larangan merokok seperti yang terlampir pada bagian hasil dari kegiatan pengabdian masyarakat ini.

3. Tahap Evaluasi

Hasil dari kegiatan pengabdian kepada masyarakat selanjutnya dievaluasi. Hal ini bertujuan untuk menilai seberapa besar keberhasilan capaian program intervensi yang telah dilakukan. Adapun tools yang digunakan dalam menilai keberhasilan program pengbdian masyarakat ini adalah post test. Akhir dari kegiatan pengabdian kepada masyarakat ini adalah pemasangan spanduk kawasan tanpa rokok di Kantor Desa Talagasari dan penyematan PIN yang berisi pesan kesehatan sebagai bentuk kampanye dukungan komitmen masyarakat dalam program ini.

\section{HASIL DAN PEMBAHASAN}

Hasil kegiatan pengabdian kepada masyarakat ini diolah dengan menggunakan analisis deskriptif dan disajikan dalam bentuk tabel. Adapun luaran dalam bentuk produk yang dihasilkan disajikan dalam bentuk gambar.

A. Gambaran Karakteristik Peserta Pengabdian Masyarakat

Gambaran karakteristik peserta kegiatan pengabdian kepada masyarakat berdasarkan kelompok umur, jenis kelamin, status merokok dan status merokok anggota keluarga serumah dapat dilihat lebih jelas pada tabel 1 .

Tabel 1. Karakterisitik Peserta

\begin{tabular}{ccc}
\hline Kelompok umur (tahun) & f & $\mathbf{\%}$ \\
\hline $21-30$ & 6 & 11 \\
$31-40$ & 17 & 31 \\
$41-50$ & 22 & 40 \\
$51-60$ & 8 & 14 \\
$\geq 61$ & 2 & 4 \\
\hline Jenis Kelamin & & \\
Laki - laki & 37 & 67,3 \\
Perempuan & 18 & 32,7 \\
\hline Status Merokok & & \\
Tidak Merokok & 18 & 32,7 \\
Merokok & 37 & 67,3 \\
\hline Status Merokok Anggota & & \\
Keluarga Serumah & & \\
\hline Tidak Merokok & 15 & 27,3 \\
Merokok & 40 & 72,7 \\
\hline
\end{tabular}


Pada tabel 1 dapat diketahui bahwa total peserta yang hadir dalam kegiatan pengabdian kepada masyarakat berjumlah 55 orang. Peserta didominasi oleh kelompok umur 31-40 tahun dan 41-50 tahun yakni masing masing $17(31 \%)$ orang dan 22 $(40 \%)$ orang. Adapun gambaran peserta kegiatan pengabdian kepada masyarakat berdasarkan karakteristik jenis kelamin diketaui bahwa peserta yang berjenis kelamin laki-laki sebanyak 37 orang atau sebesar (67,3\%). Adapun peserta yang berjenis kelamin perempuan sebanyak 18 orang atau sebesar $(32,7 \%)$.

Selanjutnya, gambaran karakteristik peserta kegiatan pengabdian kepada masyarakat pada tabel 1 berdasarkan status merokok diketahui bahwa 37 $(67,3 \%)$ orang peserta dengan status merokok dan $18(32,7 \%)$ orang peserta dengan status tidak merokok. Adapun Persentase status merokok anggota keluarga serumah sebanyak 40 orang peserta atau sebesar (72,7\%). Adapun persentase status tidak merokok anggota keluarga serumah sebanyak 15 orang peserta atau sebesar $(27,3 \%)$.

B. Gambaran Pengetahuan Tentang Bahaya Rokok dan KTR
1. Gambaran
Pengetahuan Tentang Rokok
Gambaran pengetahuan tentang bahaya rokok pada peserta kegiatan pengabdian kepada masyarakat pada tabel 2 hasil pre-test dan post-test menunjukkan bahwa skor terendah dan tertinggi pada hasil pre-test terkait pengetahuan masyarakat tentang bahaya rokok adalah masing-masing 20 dan 100 poin. Hasil ini menunjukkan hasil yang sama pada hasil post-test.

Tabel 2. Nilai Terendah dan Tertinggi Hasil Pre-test dan Post-test Tingkat Pengetahuan Tentang Bahaya Rokok

\begin{tabular}{lccc}
\hline Indikator Penilaian & N & Nilai terendah & Nilai tertinggi \\
\hline Pre-test & 55 & 20 & 100 \\
Post-test & 55 & 20 & 100 \\
\hline
\end{tabular}

Tabel 3. Nilai Mean Hasil Pre-test dan Post-test Tingkat Pengetahuan Tentang Rokok

\begin{tabular}{llcc}
\hline Indikator Penilaian & N & Mean & Standar deviasi \\
\hline Pre-test & 55 & 63,64 & 23,75 \\
Post-test & 55 & 78,91 & 21,22 \\
\hline
\end{tabular}

Pada tabel 3 dapat diketahui bahwa telah terjadi peningkatan rerata pengetahuan masyarakat terkait pengetahuan tentang rokok yakni sebesar 15,27 poin $(63,64$ menjadi 78,91 poin). Peningkatan tingkat pengetahuan masyarkat tentang bahaya rokok ini merupakan hasil evaluasi jangka pendek dari kegiatan KIE (Komunikasi, Informasi dan Edukasi) yang telah dilakukan, baik dalam bentuk penyuluhan maupun pembagian leaflet selama proses pelaksanaan kegiatan berlangsung.

Penyuluhan tentang rokok diharapkan tidak hanya merubah 
pengetahuan tetapi juga dapat merubah perilaku merokok peserta yang hadir dalam kegiatan pengabdian masyarakat ini. Rusmilawati (2016) menyatakan bahwa terdapat pengaruh penyuluhan dengan metode ceramah tentang bahaya rokok terhadap sikap perokok aktif sebelum dan setelah diberikan penyuluhan dengan nilai $\mathrm{p}=0,00$. Sementara itu, Kasman et al (2017) menyatakan bahwa media leaflet efektif dalam meningkatkan pengetahuan remaja tentang bahaya merokok dengan rerata peningkatan sebelum dan sesudah diberi pendidikan kesehatan dari kelompok leaflet adalah 36,67. Desain leaflet tentang bahaya rokok yang disajikan saat penyuluhan pada kegiatan pengabdian masyarakat dapat dilihat pada gambar 2 .
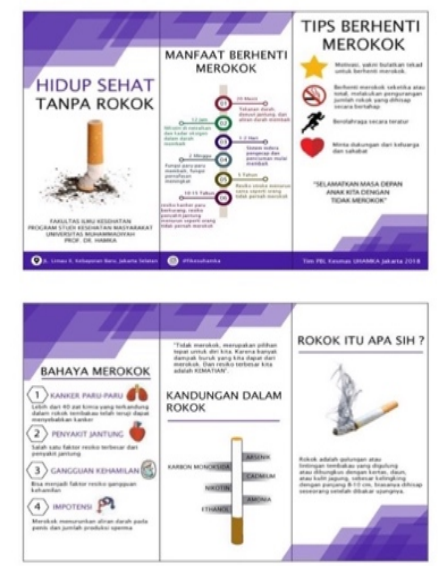

Gambar 2. Leaflet Tentang

Bahaya rokok

Pada pelaksanaan kegiatan pengabdian kepada masyarakat ini, juga dilakukan kegiatan pemutaran video pendek tentang bahaya rokok, kandungan rokok dan manfaat berhenti merokok.
Upaya peningkatan pengetahuan masyarakat dengan menggunakan video merupakan salah satu metode sangat efektif. Hal ini sejalan dengan metode serupa yang dilakukan oleh Lestari et al (2013) pada kelompok remaja yang menyatakan bahwa penggunaan media video dapat membantu memperjelas informasi terkait efek yang ditimbulkan akibat dari perilaku merokok.

2. Gambaran Pengetahuan Kawasan Tanpa Rokok

Selain melakukan penyuluhan tentang bahaya rokok, pada kegiatan pengabdian kepada masyarakat ini juga dilakukan penyuluhan terkait pentingnya kawasan tanpa rokok. Hasil dari penyuluhan terkait kawasan tanpa rokok menunjukkan bahwa nilai terendah dan nilai tertinggi pada hasil pre-test terkait pengetahuan masyarakat tentang rokok adalah masing-masing 0 dan 80 poin. Sedangkan, hasil nilai terendah dan nilai tertinggi pada hasil post test terkait pengetahuan masyarakat tentang rokok adalah masing-masing 20 dan 80 poin. Untuk lebih jelasnya dapat dilihat pada tabel 4. Pada perhitungan skor rerata (mean) pengetahuan masyarakat tentang kawasan tanpa rokok menunjukkan bahwa telah terjadi peningkatan pengetahuan masyarakat terkait kawasan tanpa rokok yakni sebesar 16,00 poin (31,27 menjadi 47,27 poin) seperti yang disajikan pada tabel 5 . 
Tabel 4. Nilai Terendah dan Tertinggi Hasil Pre-test dan Post-test Tingkat Pengetahuan Tentang KTR

\begin{tabular}{lccc}
\hline Indikator Penilaian & N & Nilai terendah & Nilai tertinggi \\
\hline Pre-test & 55 & 0 & 80 \\
Post-test & 55 & 20 & 80 \\
\hline
\end{tabular}

Tabel 5. Hasil Perhitungan Skor Tingkat Pengetahuan Tentang KTR

\begin{tabular}{lccc}
\hline Indikator Penilaian & N & Mean & Standar deviasi \\
\hline Pre-test & 55 & 31,27 & 18,36 \\
Post-test & 55 & 47,27 & 20,13
\end{tabular}

Kegiatan penyuluhan terkait bahaya rokok dan kawasan tanpa rokok terdokumentasi pada gambar 3 .

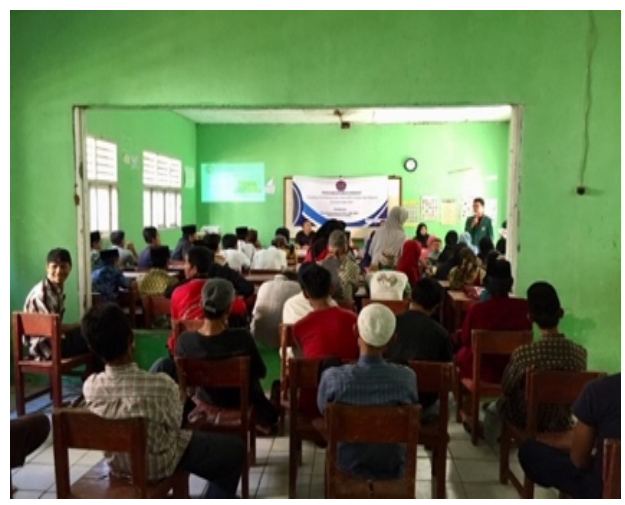

Gambar 3. Kegiatan Penyuluhan

C. Kegiatan Pendukung Upaya Berhenti Merokok dan Komitmen Penererapan KTR

Upaya menambah wawasan terkait bahaya rokok dan mendukung komitmen berhenti merokok serta penerapan KTR di Kantor Desa Talagasari, pada pengabdian kepada masyarakat ini juga dilakukan beberapa kegiatan pendukung berikut:

1. Pembagian PIN

PIN yang bertuliskan "Hidup Sehat Tanpa Rokok" ini dibagikan kepada seluruh peserta pengabdian kepada masyarakat yang diharapkan dapat menjadi pelopor dalam mewujudkan masyarakat Desa Talagasari yang mendukung adanya program Kawasan tanpa rokok di
Kantor Desa Talagasari. Desain PIN yang dibagikan kepada peserta pengabdian kepada masyarakat dapat dilihat pada gambar 4 .

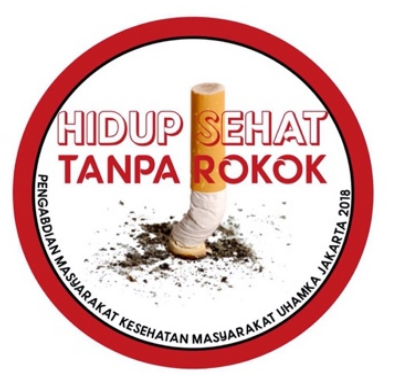

Gambar 4. Desain PIN

2. Pembagian Poster

Pembagian poster kesehatan tentang bahaya rokok dan tips berhenti merokok bertujuan untuk pengadaan poster kesehatan khususnya bahaya rokok pada sarana pelayanan publik yang ada di Desa Talagasari sehingga masyarakat Desa Talagasari dapat terpapar dengan informasi bahaya merokok ketika melakukan aktifitas di sarana pelayanan publik di Desa Talagasari. Desain poster pada kegiatan pengabdian kepada masyarakat dapat dilihat pada gambar 5. 


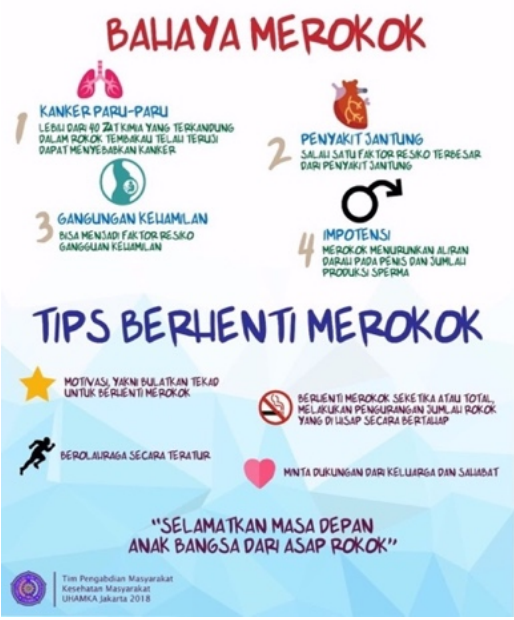

Gambar 5. Desain Poster

3. Pembagian Jam Dinding dan Goodybag

Pembagian jam dinding dan goodybag yang bertuliskan "Hidup sehat tanpa rokok" diharapkan menjadi media yang dapat mendukung komitmen perangkat Desa Talagasari menerapkan KTR. Sedangkan pembagian goodybag kepada peserta diharapkan dapat digunakan oleh peserta untuk menyimpan perlengkapan pribadi dalam melakukan aktifitas sehari - hari sehingga pesan kesehatan tentang pentingnya hidup sehat tanpa rokok dapat dijangkau oleh masyarakat. Desain Jam Dinding dan goodybag yang dibagikan kepada peserta dapat dilihat pada gambar 6.

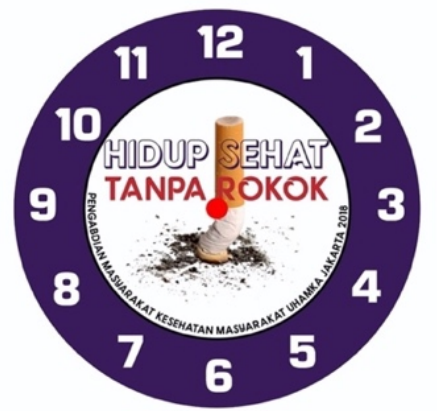

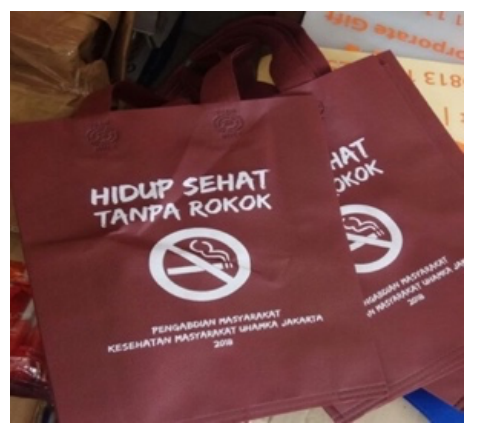

Gambar 6. Desain Jam

Dinding dan Goodybag

4. Pemasangan Tanda Larangan Merokok

Pemasangan tanda larangan merokok bertujuan untuk memberikan informasi kepada masyarakat yang beraktifitas di Kantor Desa Talagasari maupun yang berkunjung ke Kantor Desa Talagasari untuk tidak merokok sebagai bentuk komitmen masyarakat yang sepakat untuk menerapkan KTR di Kantor desa Talagasari. Desain tanda larangan merokok yang dipasang saat launching penerapan Kawasan tanpa rokok di Kantor Desa Talagasari.

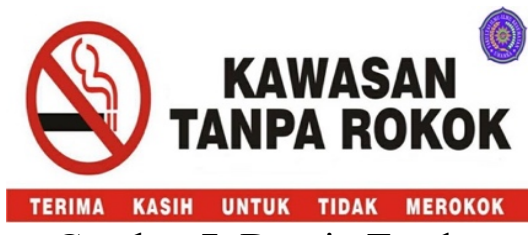

Gambar 7. Desain Tanda

Larangan Merokok

\section{SIMPULAN}

Kegiatan pengabdian kepada masyarakat yang telah dilakukan di Desa Talagasari memberikan dampak positif terhadap upaya peningkatan pengetahuan masyarakat tentang bahaya rokok dan kawasan tanpa 
rokok. Hal ini dapat dilihat dari keseriusan pemerintah desa dan besarnya antusiasme masyarakat dalam ikut berpartisipasi untuk mensukseskan kegiatan pengabdian kepada masyarakat ini.

Selain itu, terwujudnya komitmen bersama untuk menerapkan kawasan tanpa rokok di Kantor Desa Talagasari dengan melakukan pemasangan spanduk kawasan tanpa rokok merupakan bentuk tercapainya tujuan pengabdian kepada masyarakat ini. Sehingga kedepannya diharapkan perluasan kebijakan komitmen untuk tidak merokok di fasilitas pelayanan umum lainnya yang ada di Desa Talagasari.

\section{UCAPAN TERIMA KASIH}

Kami mengucapkan terima kasih kepada LPPM UHAMKA yang telah memberikan dukungan dana pada kegiatan ini. Penghargaan yang sebesar-besarnya juga kami berikan kepada Perangkat Desa dan Masyarakat Desa Talagasari atas kerjasamanya dan antusiasnya untuk ikut mensukseskan kegiatan ini.

\section{DAFTAR PUSTAKA}

Astuti, P. A. S., Ekaputra, I. A., Duana, I. K., Suarjana, K., Mulyawan, K. H., Kuniati, N. M., \& Bam, T. (2015). Indonesian Conference On Tobacco or Health 2015. Tobacco Control: Saves Young Generations, Save The Nations, 26-32.

Balitbang Kemenkes RI. (2018). Riset Kesehatan Dasar; RISKESDAS.

Direktorat P2PTM Kemenkes RI. (2018). 75 persen bahaya asap rokok akan dirasakan oleh perokok pasif.

Fauzi, R., Ma'ruf, M. A., Bonita,
Puspawati, N., Soewarso, K., Antojo, A., \& Bam, T. S. (2019). Hubungan Terpaan Iklan, Promosi, Sponsor Rokok dengan Status Merokok di Indonesia. Tobacco Control Support Center - Ikatan Ahli Kesehatan Masyarakat Indonesia.

Kasman, K., Noorhidayah, N., \& Persada, K. B. (2017). Studi Eksperimen Penggunaan Media Leaflet Dan Video Bahaya Merokok Pada Remaja. Jurnal Publikasi Kesehatan Masyarakat Indonesia, 4(2), 1014.

https://doi.org/10.20527/jpkmi.v $4 \mathrm{i} 2.3842$

Kemenkes RI. (2011). Pedoman Pengembangan Kawasan Tanpa Rokok. Pusat Promosi Kesehatan.

Kesmas Uhamka. (2018). Laporan PBL Desa Talagasari. Program Studi Kesehatan Msyarakat, Fakultas Ilmu - Ilmu Kesehatan Universitas Muhammadiyah Prof. Dr. Hamka.

Lestari, V. D., Umamah, M., Pramasari, A. L., \& Dharmawan, Y. (2013). Smoking Effect Video Learning Berbasis Mobile Sebagai Media Penyuluhan Kesehatan Anti Rokok. Jurnal Ilmiah Mahasiswa, 3(1), 15-20.

Peraturan Bersama Permekes \& Permendagri. (2011). Pedoman Pelaksanaan Kawasan Tanpa Rokok.

Peraturan Pemerintah Republik Indonesia. (2012). Pengamanan Bahan yang Mengandung Zat Adiktif Berupa Produk Tembakau Bagi Kesehatan. 109.

Rusmilawati. (2016). Pengaruh penyuluhan metode ceramah tentang bahaya rokok terhadap 
Rony Darmawansyah Alnur, Meita Veruswati/Aksiologiya: Jurnal Pengabdian Kepada Masyarakat. Vol. 6, No. 1, Februari 2022 Hal 8 - 17

perubahan sikap perokok aktif. Jurnal Vokasi Kesehatan, II(JULI), 113-118.

Suryantisa, I. (2018). Tembakau di Indonesia. Situasi Umum Konsumsi Temabakau Di Indonesia, ISSN 2442-7659, 0607.

Undang -Undang RI No. 36. (2009). Kesehatan. 